\title{
Desain Interior Kantor PT. Insastama dengan Konsep Industrial Modern
}

\author{
Nikita Bunga Pratiwi, Budiono, dan Mahendra Wardhana \\ Jurusan Desain Interior, Fakultas Teknik Sipil dan Perencanaan (FTSP), Institut Teknologi Sepuluh \\ Nopember (ITS) \\ Jl. Arief Rahman Hakim, Surabaya 60111 Indonesia \\ e-mail: budiono@interior.its.ac.id,-mahendra@interior.its.ac.id
}

\begin{abstract}
Abstrak-Dalam menghadapi persaingan era global, perusahaan di Indonesia harus menyusun strategi yang tepat agar memiliki keunggulan daya saing. Salah satu usaha tersebut adalah melakukan pembangunan gedung perkantoran pada area Central Business District di kota-kota besar. PT. Insastama, merupakan sebuah perusahaan industri yang memproduksi mur dan baut, serta produk metal lainnya. Perusahaan tersebut ingin mengembangkan bisnis perusahaan dengan membuka kantor cabang produknya ke wilayah Jakarta. Karena PT. Insastama membuka kantor cabang di lokasi yang baru, maka dari itu diperlukan upaya dalam pengenalan branding perusahaan agar dapat meningkatkan daya tarik konsumen. Selain branding melalui website dan sosial media lainnya, branding perusahaan juga dapat dilakukan dengan cara membuat desain interior yang menarik pada kantor. Selain memperhatikan segi kenyamanan untuk konsumen juga staff, juga terdapat penambahan fasilitas kantor yang dapat menunjang dan mempermudah pemenuhan kebutuhan konsumen. Perencanaan desain interior kantor PT. Insastama ini berdasarkan hasil analisis permasalahan, observasi, studi literatur, studi banding, wawancara dan pembagian kuisioner terhadap responden. Berdasarkan metodologi tersebut, hasil yang diperoleh adalah konsep desain interior kantor PT. Insastama dengan perpaduan langgam industrial dengan langgam modern, namun konsep tersebut tidak menghilangkan karakteristik dari PT. Insastama. Produk mur dan baut erat kaitannya dengan langgam Industrial, sedangkan langgam modern yang bersih, dan fokus pada fungsi cocok jika diterapkan pada gedung perkantoran. Dengan beberapa konsep diatas, kemudian disusun sebuah perencanaan yakni desain interior kantor PT. Insastama dengan konsep Industrial Modern. Konsep ini dibuat agar PT. Insastama semakin dikenal oleh masyarakat secara luas, sehingga produkproduk nya semakin dikenal dan sesuai dengan selera serta kebutuhan konsumen.
\end{abstract}

Kata Kunci-Desain Interior, Industrial, Kantor, Modern, Pembangunan

\section{PENDAHULUAN}

$\mathrm{M}$ ENGINGAT pesatnya pertumbuhan ekonomi di Indonesia, setiap tahunnya angka pembangunan gedung perkantoran milik perusahaan swasta maupun non swasta di kota-kota besar terus bertambah, salah satunya di wilayah Jakarta [1]. Saat ini terdapat 133 bangunan tinggi di Jakarta yang sedang dalam proses konstruksi. Menurut data Colliers International Indonesia, 43 pembangunan di antaranya merupakan gedung perkantoran [2]. Kantor berperan penting bagi perusahaan sebagai wadah kegiatan penunjang pemasaran produk, peningkatan dan pengembangan bisnis perusahaan [3]. Selain itu berguna untuk memenuhi kebutuhan konsumen dan bertujuan untuk mendekatkan perusahaan dengan konsumen. Adapun permasalahan yang sering dihadapi dalam sebuah perkantoran, antara lain :

1. Visualisasi ruangan kantor tidak menggambarkan corporate image.

2. Konsumen serta staff kantor kebanyakan merasa bosan saat berada dalam kantor.

3. Kantor membutuhkan perubahan desain interior, untuk dapat meningkatkan daya tarik konsumen dan staff.

4. Kantor perlu meningkatkan kenyaman baik secara fisik ataupun non fisik bagi konsumen dan staff kantor.

5. Perubahan layout eksisting sangat dibutuhkan guna meningkatkan efisiensi penggunaan ruang yang terbatas.

PT. Insastama adalah perusahaan industri yang spesialis memproduksi mur dan baut, serta produk metal lainnya. Sebagai perusahaan yang ingin terus mengembangkan usahanya, PT. Insastama ingin memperluas kantor cabang produknya ke wilayah Jakarta. Gedung yang digunakan sebagai perkantoran ini akan berfungsi sebagai wadah kegiatan penunjang pemasaran produk.

Berdasarkan latar belakang inilah, penulis mendesain sebuah kantor dengan konsep desain yang fresh dan inovatif. Konsep yang akan dipakai pada desain interior kantor PT.Insastama memadukan konsep industrial dengan modern. Desain interior kantor ini menarik untuk bahan kajian karena terdapat suatu tantangan baru bagi penulis, dimana mendesain kantor mur dan baut yang sangat maskulin dan industrialis. Adapun tujuan yang ingin dicapai dalam mendesain kantor PT. Insastama, yaitu :

1. Dapat menciptakan sebuah desain yang dapat merepresentasikan identitas atau image dari perusahaan.

2. Dapat mengetahui cara untuk meningkatkan daya tarik serta kenyamanan fisik konsumen dan staff selama berada di dalam kantor PT.Insastama.

3. Dapat menciptakan efisiensi penggunaan ruang berupa peletakan layout furniture, alur serta sirkulasi pada luasan kantor yang terbatas. 


\section{URAIAN PENELITIAN}

Dasain Interior Kantor PT. Insastama dengan Konsap Industrial Modem

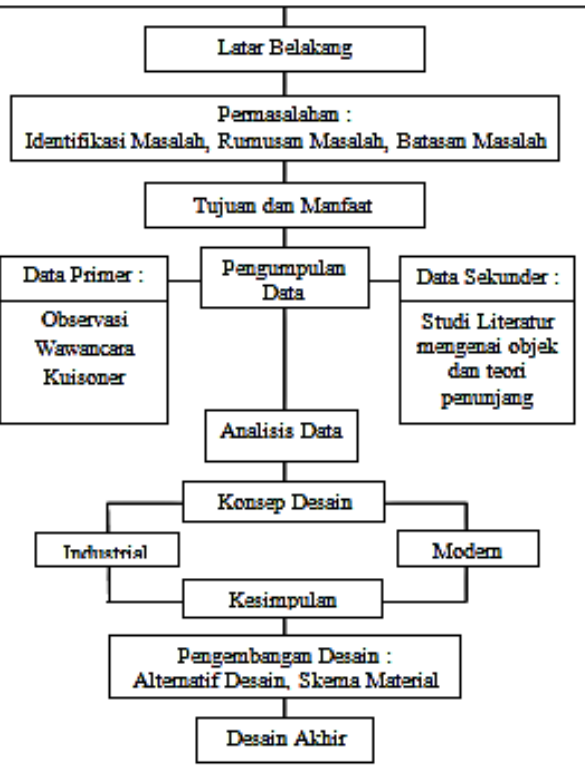

Bagan 1. Diagram metode desain

\section{A. Metode Pengumpulan dan Pengolahan Data}

Metode pengumpulan dan pengolahan data dibagi menjadi 2 yaitu Data Primer dan Data Sekunder. Data Primer didapatkan secara langsung, melalui observasi pada objek ataupun interaksi antara penulis dengan pihak yang bersangkutan, berupa wawancara atau melalui kuisioner agar mengerti kondisi lingkungan, isu dan permasalahan yang sedang diteliti. Data Sekunder diperoleh dari buku, literatur, jurnal, internet, dll yang tidak langsung berhubungan dengan pihak yang menjadi objek desain. Data sekunder diperlukan untuk menganalisis serta mendukung data primer yang ada.

\section{B. Metode Analisis Data}

Metode analisis data dilakukan untuk mendapatkan hasil dari penelitian ini dengan menganalisis semua data yang telah didapatkan dari tahap pengumpulan data. Setelah data dianalisis, nantinya akan didapatkan hasil dari penelitian ini berupa konsep desain yang sesuai dengan Kantor PT. Insastama berdasarkan penelitian yang telah dilakukan. Data observasi yang akan di analisis, diantaranya denah eksisting dan bentuk bangunan, karakteristik pengunjung dan staff kantor, dan kebutuhan fasilitas ruang kantor.

\section{KONSEP DESAIN}

\section{A. Objek Kantor}

Objek desain yang diambil merupakan sebuah perkantoran milik perusahaan yang bernama PT. Insastama. Sebuah perusahaan industri yang spesialis memproduksi mur, baut dan produk metal lainnya. Sejarah berdirinya PT. Insastama dimulai pada tahun 1970. Berawal dari tahun 1970 Soegijono Group yang sukses dalam usaha kecil ingin memperluas bisnis ke bidang manufaktur, yaitu memproduksi bisnis mur dan baut. PT Insastama mencapai reputasi nasional dengan berpartisipasi dalam proyek pembangunan nasional khususnya di daerah konstruksi.

\section{B. Konsep Makro}

Pemilihan konsep dengan tampilan yang berkarakter maskulin, perpaduan langgam industrial yang berani tampil apa adanya dengan langgam modern yang stylish dan kekinian. Dengan pemilihan warna-warna netral yang tidak mencolok, memberikan kesan tenang bagi konsumen dan staff kantor. Pada beberapa area kerja menggunakan sistem ruang open space agar area terkesan lebih luas. Selain itu agar tercipta keakraban serta kedekatan antara atasan dengan bawahan, namun tetap dapat memperoleh privasi antar area.

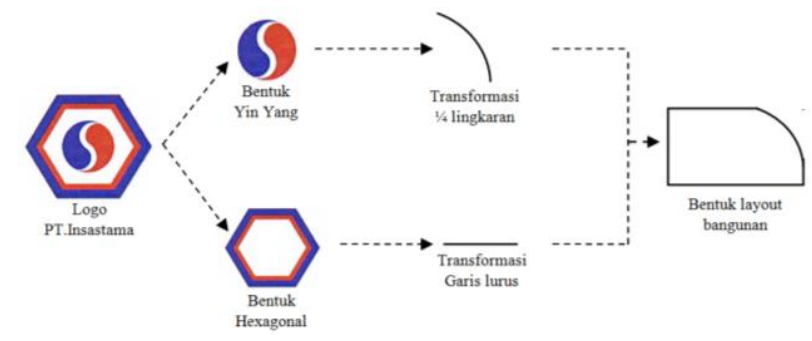

Bagan 2. Trasformasi Penerapan Bentuk

Bentuk layout bangunan diadopsi dari logo perusahaan yang berbentuk gabungan antara lambang yin dan yang dengan bentuk hexagonal atau segi enam. Karakter garis lurus memberikan kesan tegas dan minimalis. Penambahan dengan transformasi bentuk yin dan yang dubah menjadi bentuk $1 / 4$ lingkaran memberikan kesan yang tidak terlalu kaku.
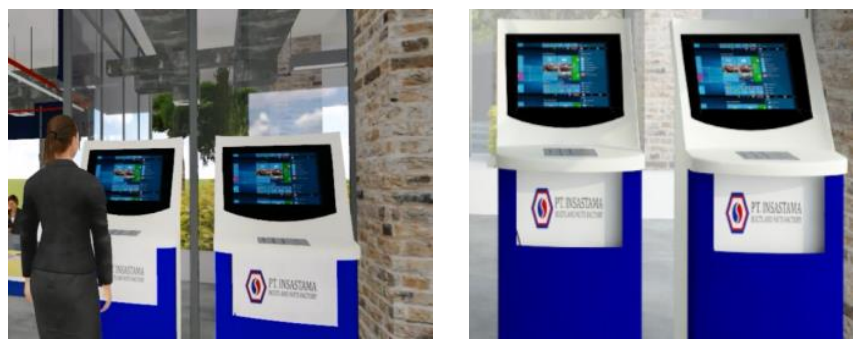

Gambar 1. Desain Mesin e-KiosK

Pada konsep desain kantor PT. Insastama terdapat penambahan fasilitas penunjang yaitu fasilitas e-KiosK pada area resepsionis. Didalam mesin e-KiosK terdapat tampilan visual baik 2D maupun 3D, mengenai profil perusahaan, sejarah perusahaan, produk yang dimiliki perusahaan, dll. Terdapat juga fitur wayfinding yang akan membantu konsumen untuk menemukan produk mur baut yang akan dicari dengan menggunakan aplikasi yang terhubung dengan google search engine. Konsumen secara langsung dapat mencari dan mengakses web perusahaan untuk mencari produk yang akan dicari beserta harga. 


\section{Konsep Mikro}

1. Dinding

Dinding yang digunakan pada konsep desain kantor PT.Insastama ada 3 jenis, yaitu dinding semen concrete, dinding bata merah dan dinding cat polos. Untuk dinding semen dan bata merah dibiarkan terekpose karakter asli dari material dinding tersebut, agar menampilkan kesan industrial.

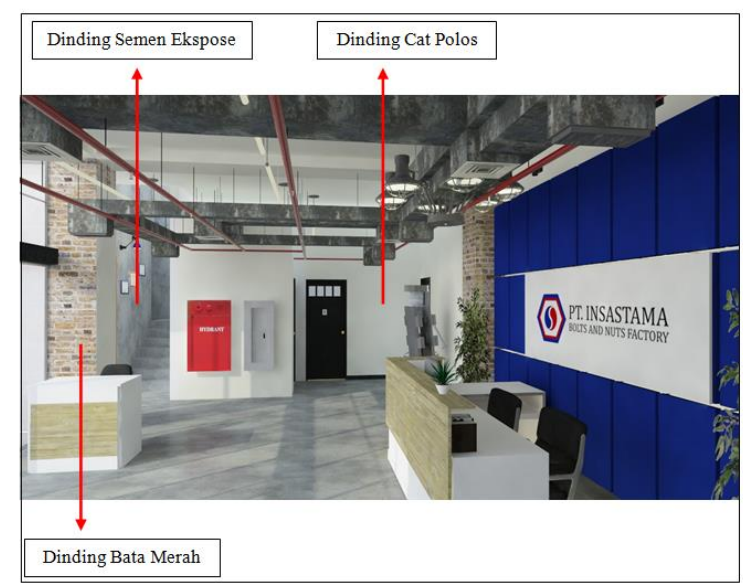

Gambar 2. Penerapan dinding pada konsep desain

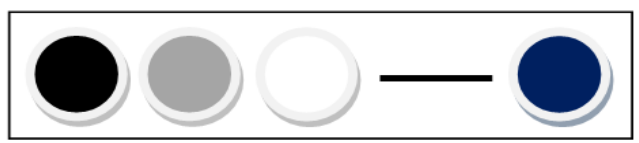

Gambar 3. Penggunaan warna pada cat dinding

Pemilihan warna dinding untuk penerapan cat polos yaitu warna-warna netral dan tidak memilih warna-warna mencolok, karena akan menimbulkan kesan yang terlalu ramai. Pemilihan warna-warna netral digunakan agar ruangan memiiki kesan luas dan bersih. Terdapat beberapa spot dinding yang memilih pengaplikasian berupa cat polos dengan warna biru, hal ini agar menggambarkan corporate image dari perusahaan. Kemudian penggunaan warna biru juga memberikan kesan maskulin. Tidak lupa memberi logo identity pada beberapa spot dinding di beberapa area, seperti area resepsionis dan area showroom.

\section{Lantai}

Penerapan lantai semen concrete diterapkan pada area kantor yang cukup luas dan bersifat publik, seperti pada resepsionis. Pengaplikasian semen concrete memberikan kesan industrial dan kesan unik pada area tersebut. Penerapan lantai karpet dilakukan pada area ruang tunggu di lobby lantai 1. Pengaplikasian karpet ini dapat membuat konsumen yang sedang menunggu, dapat merasa lebih nyaman dan lebih santai. Karpet yang dipilih dengan motif geometri dengan perpaduan warna-warna netral, juga terdapat karpet dengan warna polos biru, agar mencirikan corporate image dan agar tidak berkesan monoton.

Penerapan lantai parket pada area showroom dan pada area tunggu direktur. Pengaplikasian lantai dengan parket ini memberikan kesan santai, hangat dan nyaman. Parket yang dipilih dengan motif sejajar memanjang, dan dengan warna- warna kayu yang tidak terlalu gelap agar ruangan tampak luas dan hangat. Penggunaan lantai keramik diterapkan pada area ruang kerja, seperti pada ruang staff bagian manager operasional dan ruang presiden direktur. Lantai keramik dipilih, agar ruangan nampak bersih, stylish, dan berkesan modern. Untuk pemilihan warna yaitu warna netral seperti hitam dan putih. Lantai keramik juga diterapkan pada area kamar mandi. Pemilihan keramik pada area kamar mandi harus memperhatikan permukaan anti-slip dan bertekstur.

\section{Plafon}

Penerapan plafon ekspose pada kantor yaitu memperlihatkan langit-langit tanpa plafon. Pipa saluran air atau kabel listrik sengaja dibiarkan terlihat. Hal ini sangat mencirikan karakter industrial yang tampil apa adanya. Dalam penerapan plafon ekspose akan terlihat kolom-kolom pada bangunan kantor. Kolom-kolom tersebut dibiarkan berwarna abu-abu semen tanpa finishing atau dapat juga diberi cat dengan warna hitam atau putih.

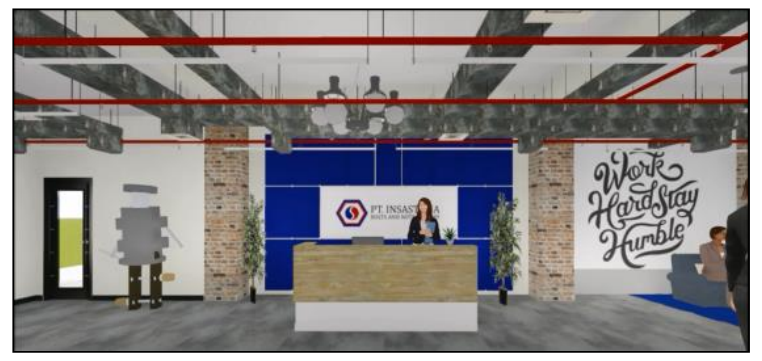

Gambar 4. Penerapan plafon ekpose pada konsep desain

\section{Furnitur}

Pengaplikasian furnitur pada kantor memadukan furnitur yang simple modern dengan furnitur khas industrial yang memiliki karakter unik dan tampil apa adanya. Kebanyakan menggunakan furniture yang bermaterialkan besi, stainlessteel, dan kayu. Furnitur didesain sederhana, plain dengan bentuk yang persegi atau bentuk lain yang geometris, garisnya jelas, lurus atau lengkung, tegas, bersih tanpa banyak hiasan. Furnitur juga harus mempertimbangkan segi antropometri, ergonomis, dan nyaman digunakan dan sesuai dengan fungsinya.

\section{Elemen Estetis}

Elemen estetis yang dipilih tidak terlalu banyak macamnya. Pemberian dekorasi pada dinding berupa typography dapat memberikan kesan industrial. Dapat juga memasang beberapa pigura pada dinding atau meletakkan lampu yang terbuat dari benda upcycle seperti pipa. Selain itu, juga terdapat elemen estetis metal figure yang memberikan kesan maskulin. 


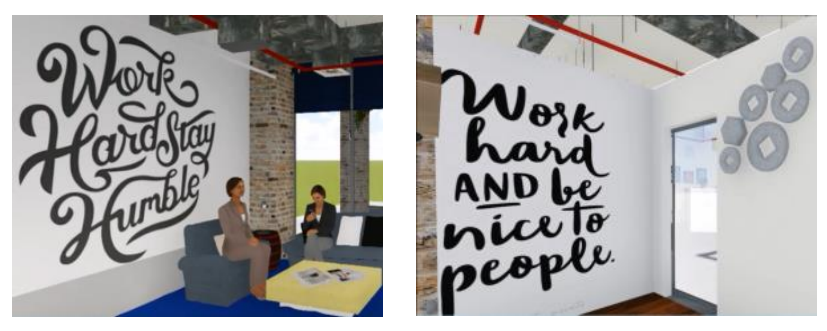

Gambar 5. Elemen estetis berupa typhography pada dinding

\section{Pencahayaan}

Pada bangunan kantor ini saat siang hari tidak memerlukan bantuan lampu dalam ruangan kantor, karena kantor didesain dengan memiliki banyak bukaan. Sehingga pencahayaan alami yang didapat dari sinar matahari dapat dimanfaatkan secara optimal.
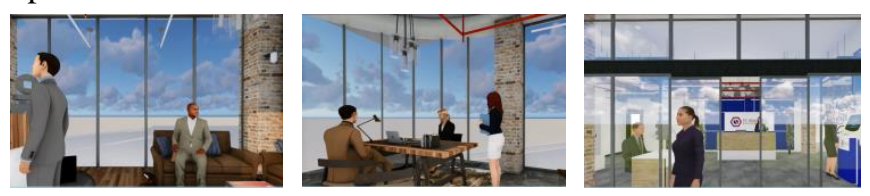

Gambar 6. Pencahayaan alami pada kantor

Untuk pencahayaan buatan utama yaitu menggunakan lampu jenis LED. Lampu LED dapat menghemat energi sampai dengan $60 \%$ jika dibandingkan dengan lampu biasa. Pada konsep ini, pengaplikasian pada kantor kebanyakan menggunakan lampu LED jenis tube. Pada beberapa titik spot dinding, terdapat lampu pijar yang digunakan sebagai lampu aksen yang mempercantik tampilan ruangan.

\section{Penghawaan}

Konsep penghawaan pada desain interior kantor PT. Insastama ini kebanyakan menggunakan penghawaan buatan. Karena bangunan memiliki banyak bukaan berupa jendela mati, sehingga penghawaan alami yang masuk tidaklah banyak. Pada area kantor dari lantai 1 hingga lantai 4, secara keseluruhan menggunakan penghawaan buatan. Untuk basement dan rooftop menggunakan penghawaan alami.

Penghawaan buatan yang digunakan adalah AC jenis sentral. Penggunaan AC central dikarenakan sistem kantor yang menggunakan plafon ekspose, sehingga AC central sangat cocok dan dapat memberikan penghawaan secara menyeluruh. Dengan AC central, pengunjung maupun para staf dapat merasa sejuk dan merasa nyaman didalam kantor.

\section{DESAIN AKHIR}

\section{A. Area Terpilih 1: Lobby}

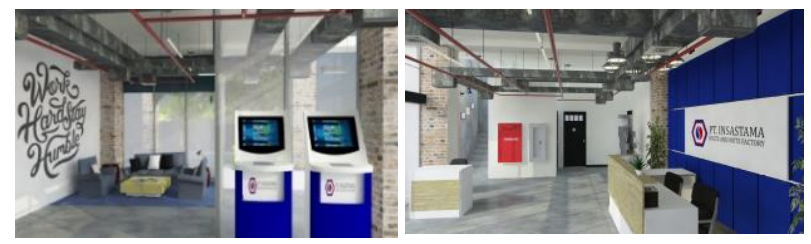

Gambar 7. Tampak view area terpilih 1 (a) Tampak view area terpilih 1 (b)

Pada area lobby terdapat mesin e-KiosK yang membantu konsumen mencari dan mengetahui produk serta bertransaksi.
Untuk penggunaan material lantai yaitu polished concrete. Pada kolom dinding menggunakan produk dari Conblog, yaitu produk flexitile tipe facebricks. Kemudian pemilihan warna biru sebagai warna aksen pada ruangan memberikan kesan sejuk dan tenang, serta mencirikan image dari PT. Insastama.

\section{B. Area Terpilih 2: Showroom dan Ruang Bagian Operasional}

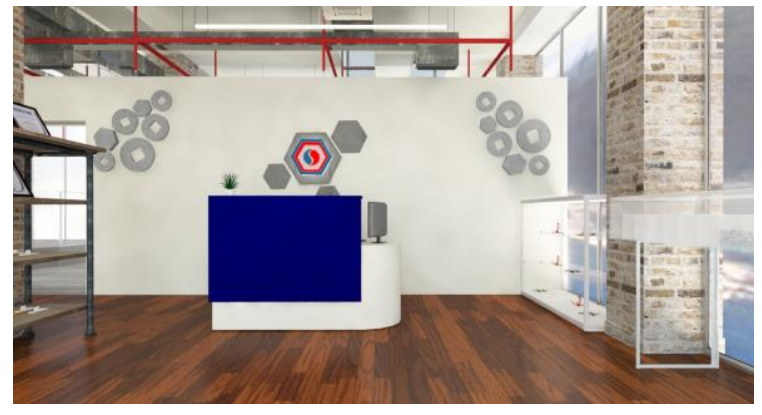

Gambar 8. Tampak view area terpilih 2, showroom

Pada area showroom, pemilihan material lantai menggunakan jenis parket merk Wood Like Tile, tipe K 2010301. Untuk dinding menggunakan finisihing warna putih polos dengan dihiasi ornamen berbentuk mur. Kemudian pemilihan warna biru pada meja admin, digunakan sebagai warna aksen pada ruangan agar tidak terlalu monoton.

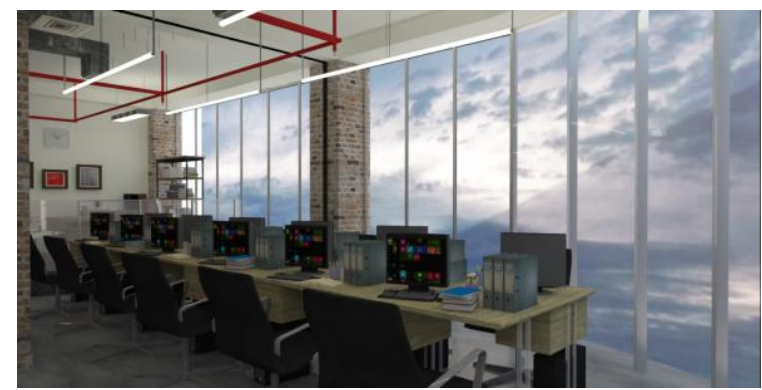

Gambar 9. Tampak view area terpilih 2, ruang bagian operasional

Jenis material lantai yang digunakan pada area staff bagian operasional adalah polished concrete. Pada material meja menggunakan perpaduan kayu dan besi. Untuk pemilihan bentuk kursi simple berwarna hitam dan berkesan modern.

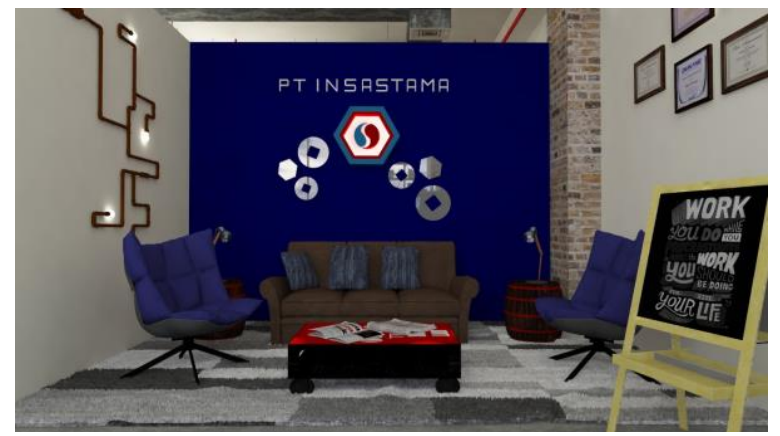

Gambar 10. Tampak view area terpilih 2, area temu klien

Pada gambar 10, dinding dihiasi dengan ornamen berbentuk mur serta terdapat lampu dinding yang terbuat dari pipa bekas. Karpet motif geometris dengan warna monochrome dipilih untuk menghiasi lantai pada area ini. Pemilihan bentuk meja serta peletakkan barrel dan papan kayu membuat tampilan 
area ini semakin industrial. Untuk pemilihan single sofa dan double sofa dipilih dengan bentuk yang simple dan modern.

\section{Area Terpilih 3 : Ruang Tunggu Direktur dan Ruang Presiden Direktur}

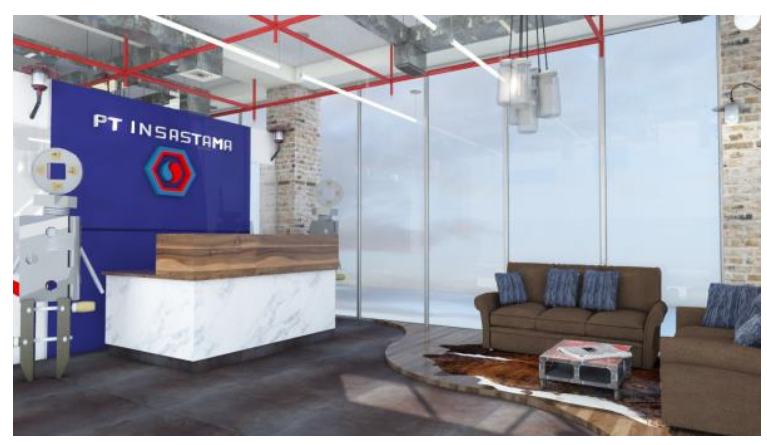

Gambar 11. Tampak view area terpilih 3, ruang tunggu direktur

Gambar 12 merupakan suasana pada ruang tunggu direktur yang terletak dilantai 4. Papan signage pada area resepsionis dipilih berwarna biru, sebagai warna aksen. Pemilihan bentuk meja terbuat dari besi serta peletakkan elemen estetis sculpture yang berbentuk mur baut membuat tampilan area ini semakin industrial.

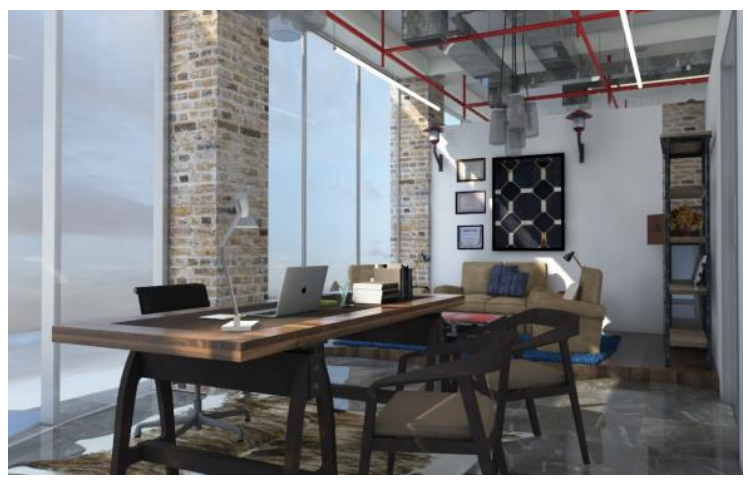

Gambar 12. Tampak view area terpilih 3, ruang presiden direktur

Gambar 13 merupakan suasana pada ruang presiden direktur, terletak di lantai 4. Dapat dilihat pada gambar diatas, kebanyakan furniture menggunakan material berbahan kayu dan besi. Untuk lantai pada area presiden direktur, mengunakan bahan keramik marmer berwarna abu-abu. Terdapat pemilihan elemen estetis berupa lampu yang diletakkan pada topless kaca.

\section{KESIMPULAN DAN SARAN}

Kesimpulan yang dapat diambil sebagai berikut :

1. Dengan menggunakan konsep desain yang baru, maka PT. Insastama dapat lebih dikenal oleh masyarakat. Hal ini dikarenakan konsep desain kantor tersebut dapat menarik konsumen serta dapat mencitrakan corporate image PT. Insastama yang merupakan sebuah perusahaan produsen mur dan baut.

2. Menampilkan interior dengan konsep baru yang fresh melalui perpaduan langgam Industrial dan langgam modern, dengan tidak menghilangkan image dari perusahaan. Dengan adanya konsep baru tersebut, dapat meningkatkan daya tarik serta minat konsumen dan staff kantor.

3. Peningkatan kenyaman baik secara fisik ataupun non fisik bagi konsumen dan staff kantor dapat dilakukan melalui beberapa hal seperti penciptaan efisiensi ruang yang terbatas, serta penataan alur dan sirkulasi kantor. Juga dapat dilakukan melalui penambahan fasilitas serta pelayanan dalam kantor.

Saran yang menjadi pertimbangan desain interior kantor PT. Insastama dengan konsep industrial modern sebagai berikut :

1. Perlu adanya upaya penyatuan corporate image perusahaan sebagai objek yang akan di desain, dengan konsep desain yang akan diterapkan.

2. Penelitian terhadap karakter serta minat konsumen dan staff terhadap sebuah kantor sangatlah penting, karena sebagai bahan acuan dan bahan referensi dalam mengolah sebuah konsep kantor yang baik dan benar.

3. Perlunya penambahan fasilitas yang dapat menunjang dan mempermudah pemenuhan kebutuhan konsumen, karena hal ini dapat mempengaruhi image dan tingkat pendapatan perusahaan.

4. Perubahan layout eksisting sangat dibutuhkan guna meningkatkan efisiensi penggunaan ruang yang terbatas.

\section{DAFTAR PUSTAKA}

[1] Anonim. (2015). DKI Jakarta. [online]. Available : https://id.wikipedia.org/wiki/Daerah_Khusus_Ibukota_Ja karta .

[2] Anonim. (2015). Data Colliers Indonesia. [online]. Available : http://www.colliers.com/en-gb/indonesia . Di

[3] Aditya. (2013). Pengertian kantor. [online]. Available : http://dilihatya.com/3213/pengertian-kantor-menurutpara-ahli-adalah. 